Document downloaded from:

http://hdl.handle.net/10251/80571

This paper must be cited as:

Bissoli, G.; Niñoles Rodenes, R.; Fresquet Corrales, S.; Palombieri, S.; Bueso Rodenas, E.; Rubio, L.; Garcia-Sanchez, MJ.... (2012). Peptidyl-prolyl cis-trans isomerase ROF2 modulates intracellular pH homeostasis in Arabidopsis. Plant Journal. 70(4):704-716. doi:10.1111/j.1365-313X.2012.04921.x

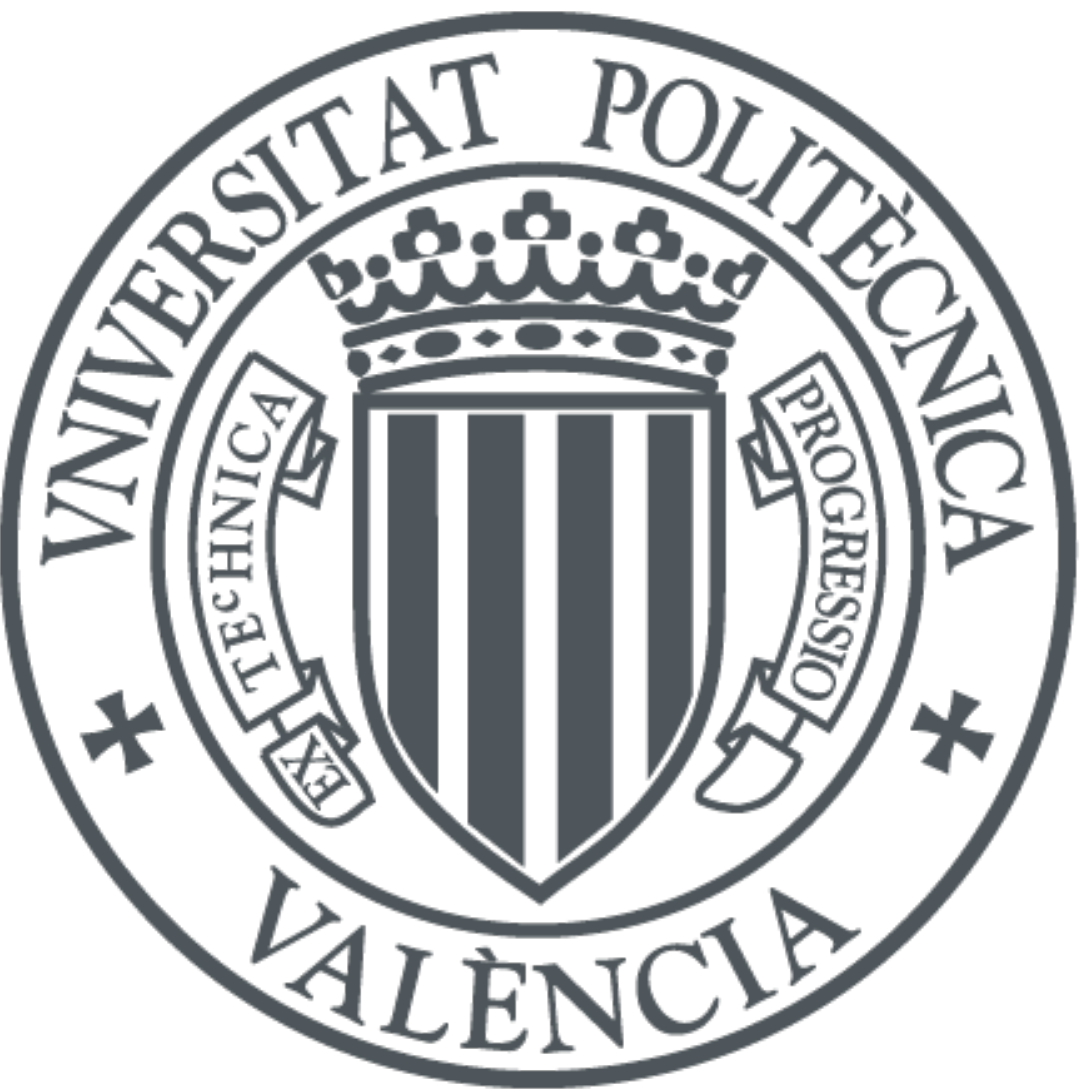

The final publication is available at

http://dx.doi.org/10.1111/j.1365-313X.2012.04921.x

Copyright Wiley

Additional Information 


\section{Peptidyl-prolyl cis-trans isomerase ROF2 modulates intracellular pH homeostasis in Arabidopsis}

Gaetano Bissoli ${ }^{1}$, Regina Niñoles ${ }^{1}$, Sandra Fresquet $^{1}$, Samuela Palombieri ${ }^{1}$, Eduardo Bueso $^{1}$, Lourdes Rubio ${ }^{2}$, María J. García-Sánchez ${ }^{2}$, José A. Fernández², José M. Mulet ${ }^{1}$, and Ramón Serrano ${ }^{1, *}$

${ }^{1}$ Instituto de Biología Molecular y Celular de Plantas, Universidad Politécnica de Valencia-CSIC, Camino de Vera, 46022 Valencia, Spain

${ }^{2}$ Departamento de Biología Vegetal, Facultad de Ciencias, Universidad de Málaga, Campus de Teatinos, 29071 Málaga, Spain

Word count: 7205

Running title: ROF2 modulates $\mathrm{pH}$ homeostasis

Key words:

$\mathrm{H}^{+}$-ATPase, $\mathrm{K}^{+}$transport, membrane potential, toxic cations, stress tolerance, Arabidopsis thaliana

*Corresponding author. Instituto de Biología Molecular y Celular de Plantas, Universidad Politécnica de Valencia-CSIC, Camino de Vera, 46022 Valencia, Spain. Tel.+ 3496387 7883; Fax: +34 96 387 7859; E-mail: rserrano@ibmcp.upv.es. Co-corresponding author is José M. Mulet (jmmulet@ibmcp.upv.es) 


\begin{abstract}
Intracellular $\mathrm{pH}$ must be regulated close to neutrality to be compatible with cellular functions but the mechanisms of $\mathrm{pH}$ homeostasis and the responses to intracellular acidification are mostly unknown. We have found in the plant Arabidopsis thaliana that intracellular acid stress, generated by weak organic acids at normal external $\mathrm{pH}$, induces several chaperone genes, including ROF2 encoding a peptidyl-prolyl cis-trans isomerase of the FK506-binding protein class. Loss of function of ROF2, and specially the double mutation of ROF2 and of its closely related gene ROF1 results in acid sensitivity. On the other hand, over-expression of ROF2 confers tolerance to intracellular acidification by increasing proton extrusion from cells. The activation of the plasma membrane proton pump ( $\mathrm{H}^{+}$-ATPase) is indirect: over-expression of ROF2 activates $\mathrm{K}^{+}$uptake, this causes depolarization of the plasma membrane that activates the electrogenic $\mathrm{H}^{+}$pump. Depolarization of ROF2-overexpressing plants explains their tolerance to toxic cations such as lithium, norspermidine and hygromycin $\mathrm{B}$, whose uptake is driven by the membrane potential. As ROF2 induction and intracellular acidification are common consequences of many stresses, this mechanism of $\mathrm{pH}$ homeostasis may be of general importance for stress tolerance.
\end{abstract}




\section{Introduction}

Living cells must regulate their intracellular $\mathrm{pH}$ within a narrow range of values close to neutrality that are compatible with cellular functions (Hochachka and Somero, 2002). In addition to this permissive role, intracellular $\mathrm{pH}$ may have regulatory functions (Felle, 2001), as observed during cell growth (Gillies, 1982; Perona and Serrano, 1988) and death (Gottlieb et al., 1996; Ludovico et al., 2001). Also, acid resistance of pathogenic bacteria is critical for survival in the stomach and inside phagosomes (Vandal et al., 2009; Krulwich et al., 2011). From an applied point of view, intracellular acidification is crucial for the action of weak acid food preservatives on spoilage microorganisms (Holyoak et al., 1996; McPherson et al., 2005).

In bacteria diverse mechanisms for $\mathrm{pH}$ sensing and cytoplasmic $\mathrm{pH}$ homeostasis have been identified (Krulwich et al, 2011). However, in eukaryotic cells and in particular in plants the components of the $\mathrm{pH}$ homeostatic machinery, including intracellular $\mathrm{pH}$ sensors, signal transducing molecules, regulators of cation transport and cellular systems most sensitive to $\mathrm{pH}$ stress are mostly unknown (Felle, 2001). Only the carboxylation-decarboxylation reactions of the "biochemical $\mathrm{pH}$ stat" proposed by Davies (1986) are usually considered for $\mathrm{pH}$ homeostasis in plants.

One general source of intracellular $\mathrm{pH}$ stress is the metabolic production of carboxylic acids, a process that probably determined the early evolution of proton pumps and chemiosmotic energy coupling in primitive cells (Raven and Smith, 1976). Fungi and plants share a proton chemiosmotic circuit at their plasma membrane, with a proton-pumping P-ATPase generating the proton electrochemical gradient that drives secondary active transporters (Serrano, 1985). The activity of this $\mathrm{H}^{+}$-ATPase is crucial for growth and tolerance to intracellular acid stress in yeast (Vallejo and Serrano, 1989; Portillo and Serrano, 1989; Holyoak et al., 1996; McPherson et al., 2005) and plants (Young et al., 1998; Haruta et al., 2010). Known mechanisms of pH homeostasis include the slightly acidic $\mathrm{pH}$ optimum of the plasma membrane $\mathrm{H}^{+}$-ATPase (Serrano, 1985) and the activation of the enzyme by phosphorylation at its C-terminal regulatory domain in response to sugar metabolism (Lecchi et al., 2007; Niittyla et al., 2007) and acidification (Eraso and Gancedo, 1987; Bobik et al., 2010). The protein kinases and signal transduction pathways involved in the regulation of $\mathrm{H}^{+}$-ATPases, however, remain unknown. Yeast (Schüller et al., 1994; Moskvina et al., 1999) and plant (Tena and Renaudin, 1998) MAP kinases are activated by multiple stresses, including acid stress, but their relationship to $\mathrm{H}^{+}$-ATPases has not been demonstrated.

As expected from the need for electrical balance during $\mathrm{H}^{+}$pumping, $\mathrm{K}^{+}$ transport is also important for tolerance to acid stress (Mulet et al., 1999; McPherson et al., 2005) and it is also activated under conditions of intracellular acidification. During $\mathrm{K}^{+}$starvation this cation leaks out of the cells in exchange for $\mathrm{H}^{+}$and the cytosol is acidified, triggering activation of $\mathrm{K}^{+}$transport. In yeast there is a $\mathrm{pH}$-sensitive interaction between the phosphatase Ppz1 and its inhibitory subunit Hal3 (Yenush et al., 2005). At low intracellular $\mathrm{pH}$ Hal3 binds and inhibits Ppz1 and this results in increased phosphorylation and activation of Trk1, a major high-affinity $\mathrm{K}^{+}$transporter inactivated by Ppz1 (Yenush et al., 2002). In Arabidopsis the major root $\mathrm{K}^{+}$transporter AKT1 is phosphorylated and activated by the dimeric calcium-activated protein kinase CBL1/9CIPK23 (Xu et al., 2006). Mutants in these regulatory systems, however, are viable and therefore other cellular systems must participate in the regulation of $\mathrm{H}^{+}$and $\mathrm{K}^{+}$ transport.

A genomic approach to investigate intracellular $\mathrm{pH}$ homeostasis has been to utilize the yeast null-mutant genomic collection to identify genes important for 
tolerance to intracellular acid stress caused by weak organic acids (Mollapour et al., 2004; Schüller et al., 2004; Mira et al., 2010a). Although many functions may have escaped the analysis because of gene redundancy and although there is some variation in the results from different laboratories, the cellular functions represented in all studies are (genes between brackets): tryptophan biosynthesis (TRP1, TRP2, TRP5), ergosterol biosynthesis (ERG2, ERG6), efflux of carboxylates (PDR12), potassium uptake (TRK1), vacuolar proton pumping (subunits of vacuolar $\mathrm{H}^{+}$-ATPase: TFP1, VMA2, VMA4), vesicle traffic (VPS16, SSO2, SAC1, ARG82), glycolysis (PFK1, PFK2) and transcription (GAL11, RPB4, WAR1). The absence of similar global studies in other organisms precludes conclusions about whether these may be considered general mechanisms.

In plants intracellular $\mathrm{pH}$ has been correlated with many regulatory phenomena, specially hypoxia (Drew, 1997; Felle, 2001) but most studies on acid stress refer to extracellular low $\mathrm{pH}$ and are concerned with acid rain and the salicylic acid pathway (Lee et al., 2006) and with solubilization of soil aluminium, a very toxic cation counteracted by root secretion of chelating di- and tri-carboxilic acids (Iuchi et al., 2007).

We have utilized Arabidopsis thaliana as a model organism to identify novel components of the intracellular $\mathrm{pH}$ homeostatic machinery. Our transcriptomic studies indicate that intracellular acidification increases expression of several chaperones also induced by heat stress and that include the peptidyl-prolyl cis-trans isomerase ROF2.

Chaperones or Heat-Shock Proteins (HSPs) of different families (HSP110, HSP90, HSP70-HSP40, Hsp60-Hsp10, small-HSPs and prolyl isomerases) participate in dissagregation and refolding of stress-denatured proteins (Nover, 1994). Prolyl isomerases not only facilitate protein folding but may also regulate the activity of other proteins (He et al., 2004; Geisler and Bailly, 2007). ROF2 and ROF1 are highly related (85\% identity) prolyl isomerases of Arabidopsis (Aviezer-Hagai et al., 2007) that play different roles during heat stress. ROF2 is not expressed under normal conditions but is highly induced by heat. On the other hand, ROF1 is expressed under normal conditions and slightly induced by heat stress (Aviezer-Hagai et al., 2007). ROF1 positively modulates thermotolerance by interacting with HSP90.1 and increasing the HSFA2mediated accumulation of chaperones of the small-HSPs family (Meiri and Breiman, 2009). ROF2, on the other hand, does not interact with HSP90.1 and negatively modulates the HSFA2-mediated expression of small HSPs (Meiri et al, 2010).

Our results indicate that $R O F 2$, and probably also $R O F 1$, plays a positive role in tolerance to intracellular acid stress. Over-expression of ROF2 activates $\mathrm{K}^{+}$uptake, depolarizes the plasma membrane and indirectly activates the electrogenic $\mathrm{H}^{+}$-ATPase. Therefore, intracellular acid stress, probably through protein denaturation, induces chaperones such as ROF2 that not only help to refold proteins but also activate $\mathrm{H}^{+}$ extrusion to restore intracellular $\mathrm{pH}$.

\section{Results}

\section{The transcriptomic response to intracellular acidification shares components with the "Misfolded Cytosolic Protein" response}

We have determined the transcriptomic response of Arabidopsis to intracellular acidification caused by acetic acid, a weak organic acid that diffuses into cells and lowers internal pH (Krebs et al., 1983; Holyoak et al., 1996). In yeast there are several 
reports on genes modulated by weak organic acids (Schüller et al., 2004; Kawahata et al., 2006; Mira et al., 2010b) but in the case of Arabidopsis no previous studies existed. The transcriptional response to lowering of external $\mathrm{pH}$ has been described in Arabidopsis (Lager et al., 2010) but these results are different to those of intracellular acidification at constant external $\mathrm{pH}$ (see below).

The total number of genes with significantly detected transcript levels was 15789, with 800 altered in expression more than 2-fold after $2 \mathrm{~h}$ incubation with 3.5 $\mathrm{mM}$ acetic acid ( $\mathrm{pH}$ 5.5). Analysis of these genes indicated that most (502 genes; about $63 \%$ ) were repressed and much less (298 genes; about $37 \%$ ) induced. The array data were confirmed by RT-PCR for 5 genes (supplementary Figure S1).

The group of repressed genes was enriched (3-5 fold with respect to the genome) in genes related to Metabolism (GO Biological process). A more detailed analysis of the 107 genes repressed more than 4-fold (see supplementary Table S1B) indicates that 26 $\%$ of the genes correspond to the category of Metabolism (sugars, aromatic compounds and lipids) and $14 \%$ to Transcription Regulators. This indicates remodeling of gene expression with reduction of metabolism.

We have compared the group of genes repressed by intracellular acid stress more than 2-fold (502 genes) with those repressed by other stresses (also more than 2-fold; Supplementary Table S2). There is significant overlap with genes repressed by heat (8.4 $\%$; 42 genes) and osmotic stress (7.2\%; 36 genes), but the overlap was only $1 \%$ (5 genes) in the case of genes repressed by low external $\mathrm{pH}$ and $0.6 \%$ (3 genes) in the case of hypoxia. The microarrays of auxin treatment, oxidative stress and infection with Pseudomonas syringae had no repressed genes in common with the acetic acid microarray. Finally, 38 \% of the genes repressed by acetic acid encode putative proteins of unknown function.

More information could be obtained from the analysis of genes induced by intracellular acid stress more than 2-fold. The functional categories (GO Biological process) enriched in the group of induced genes with respect to the genome (and with more than 5 genes in it) were: Response to heat (17-fold), Drug transport (15-fold), Response to high light intensity (15-fold) and Response to ROS (Reactive Oxygen Species; 6-fold). A more detailed analysis of the 65 genes induced more than 3-fold (see supplementary Table S1A) indicate that $17 \%$ of the genes induced by acetic acid encode putative proteins of unknown function, a much lower value than in the case of repressed genes (see above). The dominant categories of induced genes of known function are: Metabolism (14 \%), Transcription factors (12\%), Transporters (11\%), Protein folding (9\%) and Detoxification and antioxidant response (6 \%). Some of these categories correspond to the enriched GO Biological processes: Protein folding (Response to heat), Transport (Drug transport) and Detoxification and antioxidant response (Response to ROS).

As detailed in supplementary Table S2, the overlap between acetic acid-induced genes and genes induced by heat (14.1\%; 42 genes), by osmotic stress (11.4\%; 34 genes), low external pH (10.1 \%; 30 genes) and hypoxia (5.0\%; 15 genes) is small but significant. On the other hand, the overlaps with genes induced by auxin treatment (1.7 \%; 5 genes) and by oxidative stress or biotic stress (less than 2 genes or $0.7 \%$ ) were insignificant.

The most conspicuous feature of the transcriptional response of Arabidopsis to intracellular acidification is that genes encoding heat-shock proteins (chaperones) of different types are induced. As indicated in Table 1, 8 out of 10 heat-shock genes induced by intracellular acid stress were also induced by misfolded proteins produced by the proline analog azetidine-2-carboxylic acid (Sugio et al., 2009). This "Misfolded 
Cytosolic Protein" response is a subset of the wider heat-shock response and represents the pathway triggered by misfolded proteins in the cytosol.

Other genes induced by intracellular acidification in Arabidopsis include nutrient- $\mathrm{H}^{+}$symporters for sulfate (SEL1) and phosphate (PTH1 and PTH2), a channel for ammonium (AMP1.2) and two ABC-ATPases (ABCG22 and ABCB12) (see supplementary Table S1A). Intracellular acidification inhibits $\mathrm{H}^{+}$-symporters (Hueso et al., 2011) and this would explain the induction of the corresponding genes to improve nutrient uptake. ABC-ATPases may be involved in organic anion efflux as in the case of yeast Pdr12 (Piper et al., 1998). A more detailed analysis of these genes is outside the focus of the present work.

\section{Prolyl isomerase ROF2 is important for weak organic acid tolerance in Arabidopsis}

ROF2 was the only prolyl isomerase gene (out of 55 in Arabidopsis; He et al, 2004) induced by intracellular acid stress in our microarray (see Table 1). As mentioned in the introduction, ROF2 has a closely related homolog called ROF1 and both prolyl isomerases play different roles during heat stress (Aviezer-Hagai et al., 2007). ROF1 exhibits similar (but less intense) induction than ROF2 by stresses such as heat, high light, high glucose, flagellin, abscisic acid, ultraviolet light and hydrogen peroxide (see https://www.genevestigator.com/) and ROF1 was also induced (less intensively than $R O F 2$ ) by intracellular acid stress (see supplementary figure $\mathrm{S} 1$ ).

In order to investigate if induction of ROF1 and ROF2 by intracellular acid stress correlates with a positive effect of these prolyl isomerases on tolerance to this stress, we have tested germination and growth in the presence of acetic, propionic and sorbic acids of Arabidopsis transgenic plants with over-expression and null mutations of these genes. The over-expressing lines exhibit a high constitutive expression of ROF2 (supplementary Figure S2). The single mutants rof1-1 and rof2-1 (in the following rof1 and rof2) are probably null mutants because the level of the mRNAs was undetectable (supplementary Figure S3). The results of Figure 1(a) and (b) indicate that in a germination assay rof1 and rof2 single mutants are slightly more sensitive to acetic acid than wild type and this phenotype was exacerbated in the double mutant rof1 rof2. In the case of propionic acid the rof1 mutant was more sensitive than the rof 2 mutant. On the other hand over-expression of ROF2 improves tolerance to both acetic and propionic acids as determined by the appearance of green, expanded cotyledons in the germinating seeds. In addition, seedling size in the presence of the acids was greater in the plants over-expressing ROF2. This acetic and propionic acid-tolerance phenotype was observed with three independent transformed lines exhibiting high expression of ROF2 (see supplementary figure S2). The acetic acid sensitivity of the rof2 mutant could be complemented by transformation with the ROF2 gene (supplementary figure S4), suggesting that ectopic expression of ROF2 is biologically relevant.

As indicated in Figure 1(c) the sensitivity and tolerance to acetic acid were also observed after germination for 7 days in medium without acid and growing the seedlings for 12 days in the absence or presence of acetic acid. The growth of plants (measured by fresh weight) was inhibited more by acetic acid in the double mutant rof1 rof2 (49\%) than in wild type (22\%) while single mutants rof1 or rof2 exhibited similar inhibition than wild type. Plants over-expressing ROF2 were less inhibited by acetic 
acid than wild type. This indicates that the acetic acid phenotypes can be observed not only on germination but also in more adult plants.

As indicated in supplementary figure S5, over-expression of ROF2 improves germination in the presence of sorbic acid and the double mutant rof1 rof2 germinates less well than wild type in the presence of this acid. Single rof1 or rof 2 mutants exhibited little phenotype. The fact that similar phenotypes were observed with acetic, propionic and sorbic acids suggest that these phenotypes were due to intracellular acidification and not to specific metabolism of the acid.

\section{Other stress and development phenotypes of ROF mutants}

In addition to tolerance to intracellular acid stress, $R O F$ mutants exhibited phenotypes related to seed longevity and plant development. We show in Table 2 the results of a controlled deterioration test for seed longevity (accelerated aging) based on heat stress (23 h at $42{ }^{\circ} \mathrm{C}$ ) of imbibed seeds (Prieto-Daena et al., 2006). The double mutant rof1 rof 2 was more sensitive than wild type. In this assay only the double lossof-function rof1 rof2 gave phenotype: single rof1 or rof2 mutants and over-expression of ROF2 exhibited similar germination than wild type after accelerated aging of seeds.

We have observed two developmental phenotypes in plants over-expressing ROF2: decreased branching is shown in Figure 2 (a) and delayed flowering in Figure 2 (b). In the first case single and double mutants of rof1 and rof2 have no effect on branching but the single rof1 mutant or the double mutant rof1 rof2 have a decrease in bolting time as measured by both "days after germination" and "number of leaves".

\section{Over-expression of ROF2 increases acid extrusion, depolarizes the plasma membrane and stabilizes intracellular $\mathrm{pH}$ in the presence of acetic acid}

There are several possible mechanisms to improve tolerance to cytosolic acidification but increasing $\mathrm{H}^{+}$pumping out of the cells was the first one we tested. We have utilized a visual assay for $\mathrm{H}^{+}$efflux from root cells based on plates containing the $\mathrm{pH}$ indicator bromocresol purple. The yellow color of the dye in the surroundings of roots indicates external acidification and as indicated in Figure 3 (a) it was much greater in the case of ROF2 over-expressing plants than in controls. The possible phenotype of the rof1 rof 2 double mutant could not be observed with this qualitative assay for $\mathrm{H}^{+}$efflux. We have also utilized a quantitative assay based on measuring the acidification of the external medium of the plants with a sensitive $\mathrm{pH}$ meter. The results of Figure 3 (b) indicate the both the initial rate of proton efflux and the final extent of external acidification are much lower in the rof1 rof2 double mutant than in wild type. This defect could be corrected by transformation of this mutant with the ROF2 gene, again showing that ectopic expression of ROF2 is biologically relevant. Finally, over-expression of ROF2 in wild type Arabidopsis (Columbia-0) increased both the initial rate and the final extent of acidification.

The increase in external acidification upon over-expression of ROF2 can be explained by activation of the plasma membrane $\mathrm{H}^{+}$-ATPase, of $\mathrm{K}^{+}$transport or both. $\mathrm{K}^{+}$transport is required for electrical balance during proton extrusion and although anion efflux may also contribute to electrical balance, $\mathrm{K}^{+}$uptake is usually more important. These mechanisms can be differentiated by the effect of over-expression of ROF2 on the electrical membrane potential. As indicated in Figure 4, transgenic plants 
over-expressing ROF2 are depolarized, suggesting that ROF2 activates $\mathrm{K}^{+}$transport. Activation of the $\mathrm{H}^{+}$-ATPase would have produced the opposite effect (hyperpolarization). In agreement with this conclusion we have measured the plasma membrane $\mathrm{H}^{+}$-ATPase activity of control and ROF2 transgenic plants and we did not observe significant differences $(2.1 \pm 0.2$ and $1.9 \pm 0.2$ nmoles $\mathrm{Pi} / \mathrm{min} \mathrm{x}$ mg protein, respectively; average of 4 determinations \pm standard error). The single rof 2 mutant has the same membrane potential than wild type but the double rof1 rof2 mutant is hyperpolarized. The addition of acetic acid increases the potential in all genotypes, as expected from the known activation of the $\mathrm{H}^{+}$-ATPase at low $\mathrm{pH}$ described in the Introduction. However, the relative values still indicate depolarization in ROF2 overexpressing plants and hyperpolarization in the double rof1 rof2 mutant.

We have measured the intracellular (cytosolic) $\mathrm{pH}$ of Arabidopsis root cells with double-barreled microelectrodes and as indicated in Figure 4 under normal conditions this parameter is similar in all genotypes (7.3-7.4). The cytosolic $\mathrm{pH}$ decreased by 0.7 $\mathrm{pH}$ units in wild type Arabidopsis after addition of $1 \mathrm{mM}$ acetic acid (from 7.3 to 6.6). However, in transgenic plants over-expressing ROF2 no $\mathrm{pH}$ decrease was observed under the same conditions. Apparently, the enhanced capability of transgenic plants for proton extrusion rapidly compensates the influx of protons mediated by diffusion and dissociation of acetic acid inside the cells. In the rof 2 single mutant acetic acid produced an acidification of $0.1 \mathrm{pH}$ units and in the double rof1 rof2 mutant of 0.3 units. The fact that rof1 rof2 plants experience less cytosolic acidification than wild type is difficult to explain because these mutants have less capability for proton extrusion (Figure 3 (b)).

\section{ROF2 improves germination in the presence of toxic cations}

We have confirmed the depolarization of the plasma membrane in ROF2overexpressing plants by testing the sensitivity of these plants to toxic cations. In yeast indirect estimates of plasma membrane electrical potential indicate that depolarization by increased $\mathrm{K}^{+}$uptake improves the tolerance of cells to toxic cations such as sodium, lithium, norspermidine and hygromycin B (Mulet et al, 1999; Goossens et al, 2000). The interpretation is that the electrical potential (negative inside) drives the uptake of toxic cations by unknown channels and this model can now be tested in Arabidopsis plants depolarized by over-expression of ROF2. As indicated in Figure 5 overexpression of ROF2 increases the tolerance of Arabidopsis to the toxic cations lithium, norspermidine and hygromycin $\mathrm{B}$. The germination assay of stress tolerance determines the appearance of green, expanded cotyledons in the germinating seeds but the tolerance phenotype can also be appreciated by seedling size (Figure 5). These results are consistent with over-expression of ROF2 depolarizing the plasma membrane and decreasing uptake of toxic cations. On the other hand, the double mutant rof1 rof2 is more sensitive to toxic cations than wild type, a phenotype that can be explained by hyperpolarization of the plasma membrane and increased cation uptake.

\section{ROF2 activates $\mathrm{K}^{+}$transport}

Additional evidence for the hypothesis that over-expression of ROF2 activates $\mathrm{K}^{+}$ transport was provided by the improved germination of ROF2 transgenic plants in 
media with low $\mathrm{K}^{+}$levels $(10 \mu \mathrm{M})$, while the rof1 rof2 double mutant germinates less well than wild type in this medium (Figure 6 (a) and (b)).

Another confirmation of the connection between ROF2 and $\mathrm{K}^{+}$uptake was obtained by measurements of $\mathrm{Rb}^{+}$uptake in different genotypes. $\mathrm{Rb}^{+}$was utilized as $\mathrm{K}^{+}$ analog because measurements of $\mathrm{K}^{+}$uptake are complicated by the high concentration of the cation inside cells. As indicated in Figure 7, in the transgenic plants overexpressing ROF2 $\mathrm{Rb}^{+}$uptake (at $30 \mathrm{~min}$ ) is 2 -fold greater than in control plants. On the other hand, in the rof1 rof2 double mutant $\mathrm{Rb}^{+}$uptake was $70 \%$ of control plants.

\section{Discussion}

As a first step in our molecular analysis of intracellular $\mathrm{pH}$ homeostasis in Arabidopsis, we have investigated the transcriptional response to acetic acid, a weak organic acid that diffuses into cells and lowers cytosolic $\mathrm{pH}$, as determined with $\mathrm{pH}$ sensitive microelectrodes (Figure 4). Our results indicate that this response is different from responses to other stresses but include genes activated by other stresses, specially by heat stress.

The transcriptional response to heat stress has been divided into two major pathways: the "Misfolded Cytosolic Protein" response represents the pathway triggered by misfolded proteins in the cytosol and additional heat-shock responses are mediated by membrane sensors that activate MAP kinases and other pathways (Trotter et al., 2002; Sugio et al., 2009). The first one should not be confused with the "Unfolded Protein Response", an incomplete name that refers to events in the lumen of the endoplasmic reticulum. The Misfolded Cytosolic Protein pathway is probably triggered by misfolded proteins that bind to heat-shock proteins (HSP70 and HSP90) and release heat-shock transcription factors (HSFs) from inhibition by these HSPs (Sorger, 1991). The transcripcional response to intracellular acid stress shares many genes with the response to Misfolded Cytosolic Proteins (Table 1) and this coincidence suggest that a low cytosolic $\mathrm{pH}$ probably generates misfolded proteins and that damage to protein structure may be one of the most important problems generated by intracellular acid stress. This conclusion is supported by results obtained in yeast, where the transcriptional response to intracellular acidification (Schüller et al., 2004; Kawahata et al., 2006; Mira et al., 2010b) also includes many genes induced by azetidine-2carboxylic acid (Trotter et al., 2002).

It has been a surprise to find so little overlap between responses to intracellular acidification and to hypoxia because oxygen deficiency causes intracellular acidification due to the fermentative accumulation of lactic acid (Drew, 1997). The genes of two transcription factors induced by acetic acid, HRE1 and HRE2, are also induced by hypoxia and are important determinants of the transcriptional response and survival of Arabidopsis under these conditions (Licausi et al., 2010). The induction of HRE1 and HRE2 by acetic acid is accompanied by the induction of some fermentative genes modulated by these transcription factors under hypoxia: $A D H 1$ (alcohol dehydrogenase), DL4665W (lactate dehydrogenase), T28P16.12 (ribose kinase), ACO1 (ACC oxidase) and HB1 (hemoglobin) (Licausi et al., 2010). Most of the hypoxia responses, however, are probably triggered by low-oxygen levels and not by intracellular acidification, which is a late event in hypoxia (Drew, 1997). Actually, the mechanism of oxygen sensing in plants has recently been identified and it is based on an oxygen-dependent $\mathrm{N}$-end rule degradation pathway acting on the ERF-transcription factor RAP2.12 (Licause et al., 2011). This factor has an N-terminal cysteine that 
becomes oxidized in the presence of oxygen. This triggers ubiquitination and proteosomal degradation of RAP2.12. Under hypoxia RAP2.12 is stabilized, moves to the nucleus and activates anaerobic gene expression.

Dissagregation and renaturation of misfolded proteins must be crucial for tolerance to stresses known to denature intracellular proteins such as heat-shock and, accordingly, over-expression of crucial chaperones (HSPs) has been shown to protect yeast (Sanchez et al., 1992) and Arabidopsis (Nishizawa et al., 2006) against heat. Protection was also observed against other stresses, suggesting that, in addition to heat, many abiotic stresses (osmotic, salt, starvation, cold) cause protein denaturation. In the case of intracellular acid stress our transcriptomic studies provide circumstantial evidence that protein denaturation also occurs.

We have identified a chaperone, the prolyl isomerase ROF2 induced by intracellular acid stress that by over-expression improves tolerance to this stress. This was demonstrated by a germination test and by the growth of plants at later stages. The rof2 mutant had little phenotype but the double mutant rof1 rof2 gave the expected acid sensitivity. As indicated at the Introduction, ROF2 and ROF1 play different roles during heat stress (Meiri and Breiman, 2009; Meiri et al, 2010) but in our assays for seed longevity (Table 2) and germination in the presence of acetic (Figure 1) and sorbic (supplementary Figure 5S) acids the single mutants rof1 and rof2 behavior almost like wild type while the double mutant rof1 rof2 is more sensitive to accelerated aging of seeds and to germination in the presence of weak organic acids. This suggests that for these phenotypes ROF1 and ROF2 are redundant genes.

Prolyl isomerases were originally identified as receptors for the immunosuppressive drugs cyclosporin A, FK506 and rapamycin (Harding et al, 1986) and collectively referred as immunophilins. Later on these drug receptors were found to be peptidyl-prolyl cis-trans isomerases (Takahashi et al., 1989; Fisher et al., 1989; Harding et al., 1989). At present they are classified into 3 families by sequence homology and drug binding: cyclophilins (binding cyclosporin A), FKBPs (FK506binding proteins, also binding rapamycin in yeast and animals) and parvulins (ArevaloRodriguez et al., 2004; He et al., 2004). The two prolyl isomerases induced by intracellular acid stress, ROF2 and ROF1, belong to the FKBP family. Prolyl isomerases are important cellular chaperones involved in protein folding (He et al., 2004; Arevalo-Rodriguez et al., 2004). In addition, those containing tetratricopeptide domains (such as ROF2 and ROF1) modulate the heat-shock response by binding to HSP90 in yeast (Duina et al., 1998; Prodromou et al., 1999) and in Arabidopsis (Aviezer-Hagai et al., 2007). Finally, some prolyl isomerases such as TWD1/FKBP42 and PAS1/FKBP72 modulate plant growth and development (Pérez-Pérez et al., 2004; Geisler and Bailly, 2007), flowering time (Wang et al., 2010) and ABC-ATPases involved in auxin transport (Geisler et al., 2004; Bailly et al., 2008). These novel roles of prolyl isomerases are unrelated to the heat-shock response and may involve interaction of these chaperones with transcription factors, membrane transporters and other cellular proteins.

Although ROF2 probably participates in protein folding, our results indicate that it has the additional function of activating $\mathrm{K}^{+}$uptake and indirectly $\mathrm{H}^{+}$efflux to restore intracellular $\mathrm{pH}$. The electrophysiological studies conducted in Arabidopsis root cells indicate that over-expression of ROF2 depolarizes the plasma membrane (Figure 4), as expected from the observed activation of $\mathrm{K}^{+}$transport (Figure 7). Further evidence for this mechanism is provided by the observation that over-expression of ROF2 improves germination and early growth in medium with low $\mathrm{K}^{+}$(Figure 6 ) and in the presence of toxic cations such as norspermidine, lithium and hygromycin B (Figure 5). Tolerance to 
toxic cations has been interpreted by a model (Goossens et al., 2000) where electrical membrane potential, set by the relative activities of the $\mathrm{H}^{+}$-ATPase (pump) and potassium uptake (leak), determine the uptake of toxic cations. Accordingly, depolarization produced by increased $\mathrm{K}^{+}$uptake should reduce uptake and toxicity of toxic cations and this is what we have observed. In all cases the rof1 rof2 mutant exhibited opposite phenotypes than over-expression of ROF2, as expected from its decreased $\mathrm{K}^{+}$transport (Figure 7) and hyperpolarized membrane potential (Figure 4).

Our results add intracellular $\mathrm{pH}$ homeostasis and $\mathrm{K}^{+}$transport to the wide range of biological functions modulated by prolyl isomerases (in addition to protein folding, see above). The $\mathrm{K}^{+}$transporters activated by ROF2 may correspond to the major $\mathrm{K}^{+}$ uptake systems in Arabidopsis roots (AKT1 and HAK5; Gierth and Mäser, 2007). The effect of ROF2 on transporters could be direct or through regulators of the systems and in this respect the CBL1/9-CIPK23 protein kinase (Xu et al., 2006) that regulates AKT1 is a candidate to be regulated by ROF2. We are testing these hypothesis as well as the participation of auxin in ROF2 action, as suggested by the developmental phenotypes of ROF2 over-expressing plants (reduced branching and delayed bolting).

Proline isomerization may be a rate-limiting step in the conformational changes occurring during activation or transport function of $\mathrm{K}^{+}$channels/transporters. This "catalytic" mechanism has been suggested in the case of cyclophilin PIN1 from Arabidopsis (Wang et al., 2010) and animal cells (Lee et al., 2011). Alternatively, prolyl isomerases may bind to target proteins and change their conformation independently of the prolyl isomerase activity. This "stoichiometric" mechanism seems to apply in the interaction of animal cyclophilin A with rhodopsin (Baker et al., 1994), HIV-1 Gag protein (Luban, 1996) and chemotaxis receptor CD147 (Song et al., 2011) and in the case of mammalian FKBP52 and steroid hormone receptor (Riggs et al., 2007). Mutants of Arabidopsis ROF2 without prolyl isomerase activity would be needed to determine the mechanism (catalytic or stoichiometric) of regulation of $\mathrm{K}^{+}$ transport. In this respect, some mutants of the mammalian homolog of ROF2 (FKBP52) with reduced activity have been described (Riggs et al, 2007).

As a conclusion, the finding that intracellular acidification induces a chaperone like ROF2 that activates $\mathrm{K}^{+}$transport and $\mathrm{H}^{+}$extrusion establish a connection between protein folding and membrane transport that may be of general relevance to many abiotic stresses. Heat-shock has been shown to cause intracellular acidification (Weitzel et al.,1987) and osmotic stress denatures cytosolic proteins (Burkewitz et al., 2011). Therefore it is plausible that abiotic stresses cause both protein denaturation and intracellular acidification and that induction of chaperones like ROF2 has the double purpose of protein folding and $\mathrm{pH}$ homeostasis.

\section{Materials and methods}

\section{Arabidopsis growth and transformation}

Arabidopsis thaliana (Columbia-0 ecotype) plants were grown under long-day greenhouse conditions (16 h light/ $8 \mathrm{~h}$ dark, at $23^{\circ} \mathrm{C}, 130 \mu \mathrm{E} \mathrm{x} \mathrm{m}{ }^{-2} \mathrm{x} \mathrm{s}^{-1}$ and $70 \%$ relative humidity) in pots with soil-vermiculite mixture as described (Alejandro et al., 2007). 
Plants grown in pots were transformed by flower infiltration (Bechtold et al, 1993; Clough and Bent, 1998).

For in vitro culture, seeds were surface sterilized with commercial bleach and rinsed with sterile water. The agar $(0.8 \%)$ medium contained Murashige and Skoog (MS) basal salt mixture (Sigma; 0.4\%), sucrose (1\%) and $10 \mathrm{mM}$ MES buffer acid taken to $\mathrm{pH} 5.5$ with Tris base. Stratification was conducted during 3 days at $4^{\circ} \mathrm{C}$ and then plates were transferred to chambers under the conditions described above. When indicated, the medium was supplemented with $3.5 \mathrm{mM}$ acetic or propionic acids or 0.55 $\mathrm{mM}$ sorbic acid (pH 5.5 with Tris base). Germination was scored after 4-5 days. For growth in liquid culture the MS medium was prepared without agar and using suspension-culture-6 well plates (Cellstar, Greiner). Each well contained 7 ml medium and 3 seedlings that have been cultivated during 6 days in solid medium. Plates were incubated with shaking (100 rev/min) under the conditions described above.

The potassium-free medium has already been described (Alejandro et al, 2007) and for germination assays was supplemented with $10 \mu \mathrm{M} \mathrm{KCl}$.

\section{Transcriptomic response of Arabidopsis to intracellular acid stress}

Seedlings grown during 6 days in solid medium were transferred to liquid medium and grown for 13 days. Four samples (3 plants each) were incubated with $3.5 \mathrm{mM}$ acetic acid (pH 5.5) for $2 \mathrm{~h}$ and other 4 samples were incubated without acetic acid. RNA was extracted with the "RNeasy Mini Kit” (Quiagen). Thirty micrograms of RNA was retrotranscribed in the presence of modified nucleotides [5-(3-aminoallyl)-2-deoxi-UTP] by using an oligo(dT) primer. cDNA synthesis was performed at $50^{\circ} \mathrm{C}$ during at least 3 $\mathrm{h}$, using the reverse transcriptase Superscript III (Invitrogen). The cDNA was then purified using Qiaquick (Qiagen) columns and labeled with Cy3 and Cy5 dyes as recommended by the manufacturer (Amersham Biosciences). cDNAs were then purified again with Qiaquick (Qiagen) columns and the labeling was confirmed by measuring the absorbance at the appropriate wavelength, using a Nanodrop ND 1000 (Thermo Scientific).

Arabidopsis oligonucleotide microarrays were obtained from Prof. David Galbraith (http://www.ag.arizona.edu/microarray/). The chosen design for the microarray experiments was a "balanced block" design with four biological replicates and two dye swaps. For analysis, they were submerged for $45 \mathrm{~min}$ in a prehybridization solution ( $0.1 \%$ SDS, $5 x$ SSC [ $1 x$ SSC is $0.15 \mathrm{M} \mathrm{NaCl}$ plus $0.015 \mathrm{M}$ sodium citrate], $1 \%$ bovine serum albumin) at $42^{\circ} \mathrm{C}$. Microarrays were then hybridized with the labeled probes in hybridization solution $(0.1 \%$ SDS, $5 x$ SSC, $50 \%$ formamide, $0.1 \mathrm{mg} / \mathrm{ml}$ salmon sperm DNA) using hybridization chambers (Telechem) overnight at $42^{\circ} \mathrm{C}$. After the hybridization, microarrays were washed in different dilutions of SSC and SDS and then scanned to obtain digital images using a GenePix 4000B scanner (Axon Instruments) with a $10-\mu \mathrm{m}$ resolution.

Digital images from microarrays were analyzed using the GenePix 4.0 (Axon Instruments) program. Only those genes whose intensity was 2-fold higher than local background intensity in at least one of the channels used were included in the analysis. The data from the four biological replicates were analyzed and normalized by the LOWESS method using the Acuity 4.0 program (Axon Instruments), and statistical selection of genes was performed with the significance analysis application (SAM) (Tusher et al., 2001). Genes were selected as differentially expressed when the expression in acid treated cells was at least 2-fold higher or 2-fold lower than the 
expression in the untreated and when applying the significance analysis (SAM), the false discovery rate (FDR) was lower than 5.5\%.

Relevant functional categories were selected using the Gene Ontology Term Finder as described previously (Boyle et al., 2004) and over-representation of categories in our data sets was analyzed by FATIGO (http://babelomics.bioinfo.cipf.es/functional.html). The Arabidopsis acid stress microarray data have been submitted to the Gene Expression Omnibus (GEO) database (http://www.ncbi.nlm.nih.gov/geo/) and assigned the accession number GSE29259 (Arabidopsis: control-vs. acetic acid treatment). Confidential access by peer-reviewers can be achieved by username "renioro" and password "cerrallo".

\section{Comparison of genes modulated by intracellular acidification with transcriptional responses to other stresses}

With the exception of genes modulated by hypoxia (Liu et al., 2005), the microarray data were obtained from the web page (http://affymetrix.arabidopsis.info/narrays/experimentbrowse.pl) and the information is summarized in supplementary Table S2. Data from other groups were not renormalized and genes induced and repressed were only considered when the data were statistically significant with p-value 0.05 and they were up and down regulated, respectively, more than 2-fold. Times of stress were selected to maximize overlap with our acetic acid microarray ( $2 \mathrm{~h}$ treatment) and corresponded to the shortest times employed ( $1 \mathrm{~h}$ in the case of osmotic, low external $\mathrm{pH}$ and auxin treatments; $3 \mathrm{~h}$ in the case of heat and hypoxia stresses; $4 \mathrm{~h}$ in the case of bacterial infection). Concerning heat stress, although the microarray of $1 \mathrm{~h}$ treatment had more overlap with our acetic acid microarray than the one of $3 \mathrm{~h}$ (83 versus 42 in the case of induced genes) the high number of regulated genes after $1 \mathrm{~h}$ heat stress (5513 induced and 4455 repressed) made more reasonable the comparison with the $3 \mathrm{~h}$ heat treatment (1173 induced and 1773 repressed).

Overlapping (Venn diagrams) of our acetic acid microarray with other data sets with transcriptional responses to other stresses was done at the web page (http://www.bioinformatics.org/gvenn/index.htm) and the results are summarized in supplementary Table S2.

\section{Over-expression of ROF2 in Arabidopsis}

The complete ROF2 cDNA was obtained as plasmid RAFL 14-54-F14 from RIKEN (Tsukuba, Japan). The coding sequence was amplified from plasmid RAFL 14-54-F14 (RIKEN, Tsukuba, Japan) with primers upstream (5'ATACTCGAGCAGAAAATGGAAGACGATTTCGAC; Xho I site underlined) and downstream (5'-CGCGAATTCTCATGCCTTGGTGTCAATACTCAT; EcoR I site underlined), digested and ligated to binary plasmid pXCS-HAStrep (ampicillin resistance in bacteria, Basta resistance in plants and 2 X 35 S promoter; Witte et al., 2004). The 2 X 35S promoter contains a duplication of the upstream activating sequence of the cauliflower mosaic virus 35S promoter and provides very high expression levels of downstream genes (Kay et al., 1987). The recombinant plasmid was introduced into Agrobacterium tumefaciens GV3101::pMP90RK and used to transform Arabidopsis, both the wild type Columbia- 0 and the rof 2 mutant. Three transgenic lines with over-expression of ROF2 were selected and in the case of wild 
type transformation the northern analysis of the lines is shown in supplementary Figure S2.

\section{Arabidopsis mutants with loss of function of ROF genes}

T-DNA insertion mutants with loss of function of ROF1 (rof1-1; Salk_024090) and ROF2 (rof2-1; Sail_35_A02) were obtained from the European Arabidopsis Stock Centre at the University of Nottingham (NASC). The rof1-1 T-DNA insertion is in the first exon (out of 12) and the rof2-1 insertion in the sixth exon (out of 13). Both are null alleles because no expression could be detected by RT-PCR (supplementary Figure S3). Homozygous mutant plants (rof1-1/rof1-1 and rof2-1/rof2-1) were selected and crossed to identify double homozygous rof1-1/rof1-1 rof2-1/rof2-1 mutants. The double mutant was named in the following rof1 rof2.

Measurement of plasma membrane $\mathrm{H}^{+}$-ATPase activity in Arabidopsis roots: in vitro and in vivo assays

For in vitro determination of activity of the plasma membrane $\mathrm{H}^{+}$-ATPase Arabidopsis plants were grown for 18 days in vertical plates with MS medium containing no sucrose under the conditions described above. About $0.5 \mathrm{~g}$ fresh weight of roots were frozen with liquid nitrogen and homogenized with mortar and pestle. The homogenization buffer, differential centrifugation, resuspension medium and specific assay for plasma membrane $\mathrm{H}^{+}$-ATPase activity were as described (Serrano, 1988).

For in vivo assay of the plasma membrane proton pump we used qualitative and quantitative assays. In the first case plants were grown in vertical plates with normal solid MS medium for 16 days and then transferred to vertical plates of the same medium (pH 5.5) without MES buffer and with $0.003 \%$ bromocresol purple. This $\mathrm{pH}$ indicator turns yellow below pH 5.2 and after 8 h incubation the yellow color around roots indicates proton extrusion.

The quantitative assay is based on measuring the acidification of the external medium of plants with a sensitive $\mathrm{pH}$ meter (Crison GLP22 with $\mathrm{pH}$ electrode 52.08). Plants were grown for 12 days in vertical plates with normal MS medium and then transferred to a plate with sterile water and incubated $24 \mathrm{~h}$ in darkness. The starved plants (about 5 plants with $2 \mathrm{mg}$ root weight) were then incubated in a vessel with $5 \mathrm{ml}$ of MS medium without sucrose and without buffer and the $\mathrm{pH}$ was adjusted to 5.7 with $\mathrm{KOH}$. Only the roots were submerged and shaking was effected with a magnetic bar. Proton pumping was started by addition of sucrose (1\% final) and the $\mathrm{pH}$ recorded during the first 15 min. Data were analyzed with a PC computer using the GLP-PC software from Crison. Total $\mathrm{pH}$ change was $0.03-0.10 \mathrm{pH}$ units for the different samples and buffering power was calibrated by addition of $5 \mu \mathrm{l}$ of $10 \mathrm{mM} \mathrm{HCl}$ (producing a $\mathrm{pH}$ decrease of about 0.05 units).

\section{Electrophysiology of Arabidopsis root epidermal cells}


Seeds of Arabidopsis thaliana wild type (Col-0), ROF2 over-expressing lines, rof2 mutant and rof1 rof2 double mutant were surface esterilized, washed with sterile distilled water and grown aseptically in Petri dishes with agar and MS medium as described above. After $48 \mathrm{~h}$ in the dark at $4{ }^{\circ} \mathrm{C}$, seeds were grown vertically at $25{ }^{\circ} \mathrm{C}$ for 10-15 days, at a light intensity of $150 \mu \mathrm{mol} \mathrm{m} \mathrm{m}^{-2} \mathrm{~s}^{-1}$ with a photoperiod of 16/8 h light/dark.

Membrane potentials were measured using the standard glass microelectrode technique (Felle, 1981). Seedlings were mounted in a Plexiglas chamber $(1.1 \mathrm{ml}$ volume) with continuous perfusion of the assay medium (flux of $10 \mathrm{ml} \mathrm{min}^{-1}$ ), containing $0.1 \mathrm{mM} \mathrm{CaCl}_{2}, 0.1 \mathrm{mM} \mathrm{KCl}, 0.1 \mathrm{mM} \mathrm{NaCl}, 12 \mathrm{mM}$ MES-Bis tris propane (pH 5.5). Epidermal root cells (located at $\approx 0.5 \mathrm{~cm}$ from root tip) of plant seedlings were impaled with single-barrelled borosilicate glass vertically pulled, filled with $500 \mathrm{mM}$ $\mathrm{KCl}$ and connected to a high impedance differential amplifier (WPI FD223, World Precision Instruments, Saratosa, FL, USA).

Cytosolic $\mathrm{pH}$ and membrane potential was simultaneously measured using double-barrelled microelectrodes. Microelectrode pre-treatment and backfilling was similar to the $\mathrm{H}^{+}$-selective microelectrodes described previously (Felle, 1987; Fernández et al., 1999). After $30 \mathrm{~min}$ heating at $180{ }^{\circ} \mathrm{C}$, the barrels containing the sensor were silanized by the addition of one drop of dimethyldichlorosilane $(0.1 \%$ in benzene) in the blunt end of the pipette. The microelectrodes then were heated again for $60 \mathrm{~min}$ at $180{ }^{\circ} \mathrm{C}$ and backfilled with the $\mathrm{H}^{+}$-sensor, once cold. The $\mathrm{H}^{+}$-sensor was prepared by mixing the Hydrogen Ionophore II-cocktail A in a mixture of polyvinylchloride/tetrahydrofuran $\left(40 \mathrm{mg} \mathrm{ml}^{-1}\right)$ at a ratio $1 / 6(\mathrm{v} / \mathrm{v})$. The microelectrodes were filled with the $\mathrm{H}^{+}$-sensor cocktail and stored in a dry chamber (silica gel) until the evaporation of tetrahydrofuran. The microelectrode barrel containing the $\mathrm{H}^{+}$sensor was backfilled with a mixture of $500 \mathrm{mM} \mathrm{KCl}$ and $100 \mathrm{mM}$ Mes-Tris adjusted to $\mathrm{pH}$ 4.3, whereas the voltage barrel and the reference electrode were filled with $500 \mathrm{mM} \mathrm{KCl}$. The signals from the $\mathrm{H}^{+}$-selective and voltage barrels were measured and simultaneously subtracted by the high impedance differential amplifier. The $\mathrm{H}^{+}-$ selective microelectrodes were calibrated before and after the measurements with buffers solution containing $96 \mathrm{mM} \mathrm{KCl}$ and $2.5 \mathrm{mM}$ Mes - Bis tris propane (pH 5.3; 6.3 and 8.3). Calibrations curves showed slopes round $49 \mathrm{mV} / \mathrm{pH}$ unit.

\section{Determination of rubidium uptake in Arabidopsis}

Potassium transport was measured by using rubidium as a tracer and the method has been described (Alejandro et al, 2007). Basically, Arabidopsis seedlings were germinated and grown in potassium-free medium and after 15 days incubated in the same medium with $2 \mathrm{mM} \mathrm{RbCl}$. At the indicated times samples were taken, washed, extracted with nitric acid, centrifuged and $\mathrm{Rb}^{+}$determined in the supernatant by atomic absorption spectrophotometry.

\section{Acknowledgements}

This work was supported by grants BFU2008-00604 of MICINN (Madrid) and PROMETEO/2010/038 of “Consellería de Educación" (Valencia). We thank Dr. Eugenio Grau (Sequencing Service, IBMCP, Valencia) for sequencing of the different 
genes and Dr. Vicente Fornés (Instituto de Tecnología Química, Valencia) for assistance with the atomic absorption spectrophotometry. None of the authors has a conflict of interest to declare.

\section{Short legends for supplementary material}

Table S1. Genes modulated by intracellular acidification. Table S1A. Genes induced by intracellular acidification (3-fold and more) in the plant Arabidopsis thaliana. Table S1B. Genes repressed (4-fold and more) by intracellular acidification in the plant Arabidopsis thaliana

Table S2. Information about the microarray experiments compared in the present work

Supplementary figures. Figure S1. Confirmation of 3 induced and 2 repressed genes of the acetic acid microarray. Figure S2. Northern analysis of ROF2 expression in three transgenic lines that over-express ROF2 (numbers 7, 16 and 17) and in non-transformed control (ctrl). Figure S3. The rof1-1 and rof2-1 alleles do not express the respective genes (less than $5 \%$ ).

\section{References}

Alejandro, S., Rodriguez, P.L., Bellés, J.M., Yenush, L., García-Sanchez, M.J., Fernández, J.A. and Serrano, R. (2007) An Arabidopsis quiescin-sulphydryl oxidase regulates cation homeostasis at the root symplast-xylem interface. EMBO J. 26, 3203-3215.

Arevalo-Rodriguez, M., Wu, X., Hanes, S.D. and Heitman, J. (2004) Prolyl isomerases in yeast. Front. Biosci. 9, 2420-2446.

Aviezer-Hagai, K., Skovorodnikova, J., Galigniana, M., Farchi-Pisanty, O., Maayan, E., Bocovza, S., Efrat, Y., von Koskull-Döring, P., Ohad, N., and Breiman, A. (2007) Arabidopsis immunophilins ROF1 (AtFKBP62) and ROF2 (AtFKBP65) exhibit tissue specificity, are heat-stress induced, and bind HSP90. Plant Mol. Biol. 63, 237-255.

Bailly, A., Sovero, V., Vincenzetti, V., Santelia, D., Bartnik, D., Koenig, B.W., Mancuso, S., Martinoia, E. and Geisler, M. (2008) Modulation of Pglycoproteins by auxin transport inhibitors is mediated by interaction with immunophlins. J. Biol. Chem. 283, 21817-21826.

Baker, E.K., Colley, N.J. and Zuker, C.S. (1994) The cyclophilin homolog NinaA function as a chaperone, forming a stable complex in vivo with its protein target rhodopsin. EMBO J. 13, 4886-4895.

Bechtold, N., Ellis, J. and Pelletier, G. (1993) In planta Agrobacterium mediated gene transfer by infiltration of adult Arabidopsis plants. CR Acad Sci Paris/Life Sci 316, 1194-1199.

Bobik, K., Boutry, M. and Duby, G. (2010) Activation of the plasma membrane $\mathrm{H}^{+}$ATPase by acid stress. Plant Signal Behav 5, 681-683.

Boyle, E.I., Weng, S., Gollub, J., Jin, H., Botstein, D., Cherry, J.M. and Sherlock, G. (2004) GO::TermFinder-open source software for accessing gene ontology information and finding significantly enriched gene ontology terms associated with a list of genes. Bioinformatics 20, 3710-3715. 
Burkewitz, K., Choe, K. and Strange, K. (2011) Hypertonic stress induces rapid and widespread damage in C. elegans. Am. J. Physiol. Cell Physiol. 301, C566-576.

Clough, S.J. and Bent, A.F. (1998) Floral dip: a simplified method for Agrobacteriummediated transformation of A. thaliana. Plant J. 16, 735-743.

Drew, M.C. (1997) Oxygen deficiency and root metabolism: injury and acclimation under hypoxia and anoxia. Annu. Rev. Plant Physiol. Plant Mol. Biol. 48, 223250.

Davies, D.D. (1986) The fine control of cytosolic pH. Physiol. Plant. 67, 702-716

Duina, A.A., Kalton, H.M., Gaber, R.F. (1998) Requirement for Hsp90 and a CyP40-type cyclophilin in negative regulation of the heat shock response. J. Biol. Chem. 273, 18974-18978.

Eraso, P. and Gancedo, C. (1987) Activation of yeast plasma membrane ATPase by acid $\mathrm{pH}$ during growth. FEBS Lett. 224, 187-192.

Felle, H.H. (1981) A study of the current-voltage relationships of electrogenic and passive membrane elements in Riccia fluitans. Biochim. Biophys. Acta 602, 180195.

Felle, H.H. (1987) Proton transport and pH control in Sinapis alba root hairs: a study carried out with double-barreled pH micro-electrodes. J. Exp. Bot. 38, 340-354.

Felle, H.H. (2001) pH: signal and messenger in plant cells. Plant. Biol. 3, 577-591.

Fernández, J.A., García-Sánchez, M.J. and Felle, H. (1999) Physiological evidence for a proton pump and sodium exclusion mechanisms at the plasma membrane of the marine angiosperm Zostera marina L. J. Exp. Bot. 50, 1763-1768.

Fisher, G., Wittmann-Liebold, B., Lang, K., Kiefhaber, T., Schmid, F.X. (1989) Cyclophilin and peptidyl-prolyl cis-trans isomerase are probably identical proteins. Nature 337, 476-478

Geisler, M., Girin, M., Brandt, S., Vincenzetti, V., Plaza, S., Paris, N., Kobae, Y., Maeshima, M., Billion, K., Kolukisaoglu, U.H., Schulz, B. and Martinoia, E. (2004) Arabidopsis immunophilin-like TWD1 functionally interacts with vacuolar ABC transporters. Mol. Biol. Cell 15: 3393-3405.

Geisler, M. and Bailly, A. (2007) Tête-à-tête: the function of FKBPs in plant development. Trends Plant Sci. 12, 465-473.

Gierth, M. and Mäser, P. (2007) Potassium transporters in plants-Involvement in $\mathrm{K}^{+}$ acquisition, redistribution and homeostasis. FEBS Lett. 581, 2348-2356.

Gillies, R.J. (1982) Intracellular $\mathrm{pH}$ and proliferation in yeast, Tetrahymena and sea urchin eggs. In Intracellular pH: its measurement, regulation, and utilization in cellular functions (Nuccitelli, R. and Deamer, D.W., eds), New York, NY: Alan R Liss, pp 341-359.

Goossens, A., de la Fuente, N., Forment, J., Serrano, R. and Portillo, F. (2000) Regulation of yeast $\mathrm{H}^{+}$-ATPase by protein kinases belonging to a family dedicated to activation of plasma membrane transporters. Mol. Cell. Biol. 20, 7654-7661.

Gottlieb, R.A., Nordberg, J., Skowronski, E. and Babior, B.M. (1996) Apoptosis induced in Jurkat cells by several agents is preceded by intracellular acidification. Proc Natl Acad Sci USA 93, 654-658.

Harding, M.W., Hanschumacher, R.E. and Speicher, D.W. (1986) Isolation and amino acid sequence of cyclophilin. J. Biol. Chem. 261, 8547-8555.

Harding, M.W., Galat, A., Uehling, D.E. and Schreiber, S.L. (1989) A receptor for the immunosuppressant FK506 is a cis-trans peptidyl-prolyl isomerase. Nature 341, 758-760. 
Haruta, M., Burch, H.L., Nelson, R.B., Barret-Wilt, G., Kline, K.G., Mohsin, S.B., Young, J.C., Otegui, M.S. and Sussman, M.R. (2010) Molecular characterization of mutant Arabidopsis plants with reduced plasma membrane proton pump activity. J. Biol. Chem. 285, 17918-17929.

He, Z., Li, L. and Luan, S. (2004) Immunophilins and parvulins. Superfamily of peptidyl prolyl isomerases in Arabidopsis. Plant Physiol. 134, 1248-1267.

Hochachka, P.W. and Somero, G.N. (2002) Biochemical Adaptation. Mechanism and Process in Physiological Evolution. Oxford: Oxford University Press, pp 345-351.

Holyoak, C.D., Stratford, M., McMullin, Z., Cole, M.B., Crimmins, K., Brown, A.J.P. and Coote, P.J. (1996) Activity of the plasma membrane $\mathrm{H}^{+}$-ATPase and optimal glycolytic flux are required for rapid adaptation and growth of Saccharomyces cerevisiae in the presence of the weak-acid preservative sorbic acid. App. Environ. Microbiol. 62, 3158-3164.

Hueso, G., Aparicio-Sanchis, R., Montesinos, C., Lorenz, S., Murguía, J.R. and Serrano, R. (2011) A novel role of protein kinase Gcn2 in yeast tolerance to intracellular acid stress. Biochem. J. in press, doi:10.1042/BJ20111264

Iuchi, I., Koyama, H., Iuchi, A., Kobayashi, Y., Kitabayashi, S., Kobayashi, Y., Ikka, T., Hirayama, T., Shinozaki, K. and Kobayashi, M. (2007) Zinc finger protein STOP1 is critical for proton tolerance in Arabidopsis and coregulates a key gene in aluminum tolerance. Proc. Natl. Acad. Sci. USA 104, 9900-9905.

Kawahata, M., Masaki, K., Fujii, T. and Iefuji H (2006) Yeast genes involved in response to lactic acid and acetic acid: acidic conditions caused by the organic acids in Saccharomyces cerevisiae cultures induce expression of intracellular metal metabolism genes regulated by Aft1p. FEMS Yeast Res. 6, 924-936.

Kay, R., Chan, A., Daly, M. and McPherson, J. (1987) Duplication of CaMV 35S promoter sequences creates a strong enhancer for plan genes. Science 236, 12991302.

Kim, J.I., Sharkhuu, A., Jing, J.B., Li, P., Jeong, J.C., Baek, D., Lee, S.Y., Blakeslee, J.J., Murphy A.S., Bohnert, H.J., Hasegawa, P.M., Yun, D.-J. and Bressan, R. A. (2007) yucca6, a dominant mutation in Arabidopsis, affects auxin accumulation and auxin-related phenotypes. Plant Physiol. 145: 722-735.

Krebs, H.A., Wiggins, D., Stubbbs, M., Sols, A. and Bedoya, F. (1983) Studies on the mechanism of the antifungal action of benzoate. Biochem. J. 214, 657-663.

Krulwich, T.A., Sachs, G. and Padan, E. (2011) Molecular aspects of bacterial pH sensing and homeostasis. Nature Rev. Microbiol. 9, 330-343.

Lager, I., Andreasson, O., Dunbar, T.L., Andreasson, E., Escobar, M.A. and Rasmusson, A.G. (2010) Changes in external pH rapidly alter plant gene expression and modulate auxin and elicitor responses. Plant Cell Environ. 33, 1513-1528.

Lecchi, S., Nelson, C.J., Allen, K.E., Swaney, D.L., Thompson, K.L., Coon, J.J., Sussman, M.R. and Slayman, C.W. (2007) Tandem phosphorylation of Ser-911 and Thr-912 at the C terminus of yeast plasma membrane $\mathrm{H}^{+}$-ATPase leads to glucose-dependent activation. J. Biol. Chem. 282, 35471-35481.

Lee, Y., Park, J., Im, K., Kim, K., Lee, J., Lee, K, Park, J.-A., Lee, T.-K., Park, D.-S., Yang, J.-S., Kim, D. and Lee, S. (2006) Arabidopsis leaf necrosis caused by simulated acid rain is related to the salicylic acid signaling pathway. Plant Physiol. Biochem. 44, 38-42. 
Lee, T.H., Chen, C.H., Suizu, F., Huang, P., Schene-Fischer, C., Daum, S., Zhang, Y.J., Goate, A., Chen, R.H., Zhou, X.Z. and Lu, K.P. (2011) Death-associated protein kinase 1 phosphorylates Pin 1 and inhibits its prolyl isomerase activity and cellular function. Mol. Cell 42, 147-159.

Licausi, F., van Dongen, J.T., Giuntoli, B., Novi, G., Santaniella, A., Geigenberger, P. and Perata, P. (2010) HRE1 and HRE2, two hypoxia-inducible ethylene response factors, affect anaerobic responses in Arabidopsis thaliana. Plant J. 62, 302-315.

Licausi, F., Kosmacz, M., Weits, D.A., Giuntoli, B., Giorgi, F.M., Voesenek, L.A.J., Perata,P. and van Dongen, J.T. (2011) Oxygen sensing in plants is mediated by an N-end rule pathway for protein stabilization. Nature 479, 419-422.

Liu, F., VanToai, T., Moy, L.P., Bock, G., Linford, L.D. and Quackenbush, J. (2005) Global transcription profiling reveals comprehensive insights into hypoxc response in Arabidopsis. Plant Physiol. 137, 1115-1129.

Luban, J. (1996) Absconding with the chaperone: essential cyclophilin-Gag interaction in HIV-1 virions. Cell 87, 1157-1159.

Ludovico, P., Sousa, M.J., Silva, M.T., Leao, C. and Corte-Real, M. (2001) Saccharomyces cerevisiae commits to a programmed cell death process in response to acetic acid. Microbiology 147, 2409-2415.

Mcpherson, N., Shabala, L., Rooney, H., Jarman, M.G. and Davies, J.M. (2005) Plasma membrane $\mathrm{H}^{+}$and $\mathrm{K}^{+}$transporters are involved in the weakacid preservative response of disparate food spoilage yeast. Microbiology 151,1995-2003.

Meiri, D. and Breiman, A. (2009) Arabidopsis ROF1 (FKBP62) modulates thermotolerance by interacting with HSP90.1 and affecting the accumulation of HsfA2-regulated sHSPs. Plant J. 59, 387-399.

Meiri, D., Tazat, K., Cohen-Peer, R., Farchi-Pisanty, O., Aviezer-Hagai, K., Avni, A. and Breiman A. (2010) Involvement of Arabidopsis ROF2 (FKBP65) in thermotolerance. Plant Mol. Biol. 72, 191-203

Mira, N.P., Palma, M., Guerreiro, J.F. and Sá-Correia, I. (2010a) Genomewide identification of Saccharomyces cerevisiae genes required for tolerance to acetic acid. Microbial Cell Factories 9, 79-85.

Mira, N.P., Becker, J.D. and Sá-Correia, I. (2010b) Genome expression program involving the Haa1p-regulon in Saccharomyces cerevisiae response to acetic acid. Omics 14, 587-601.

Mollapour, M., Fong, D., Balakrishnan, K., Harris, N., Thompson, S., Schüller, C., Kuchler, K. and Piper, P.W. (2004) Screening the yeast deletant mutant collection for hypersensitivity and hyper-rsistance to sorbate, a weak organic acid food preservative. Yeast 21, 927-946.

Moskvina, E., Imre, E.-M. and Ruis, H. (1999) Stress factors acting at the level of the plasma membrane induce transcription via the stress response element (STRE) of the yeast Saccharomyces cerevisiae. Mol. Microbiol. 32, 1263-1272.

Mulet, J.M., Leube, M.P., Kron, S.J., Ríos, G., Fink, G.R. and Serrano, R. (1999) A novel mechanism of ion homeostasis and salt tolerance in yeast: the Hal4 and Hal5 protein kinases modulate the Trk1-Trk2 potassium transporter. Mol. Cell. Biol. 19 3328-3337.

Niittyla, T., Fuglsang, A.T., Palmgren, M.G., Frommer, W.B. and Schulze, W.X. (2007)Temporal analysis of sucrose-induced phosphorylation 
changes in plasma membrane proteins of Arabidopsis. Mol. Cell. Proteomics 6, 1711-1726.

Nishizawa, A., Yabuta, Y., Yoshida, E., Maruta, T., Yoshimura, K. and Shigeoka, S. (2006) Arabidopsis heat shock transcription factor A2 as a key regulator in response to several types of environmental stress. Plant J. 48, 535-547.

Nover, L. (1994) The heat stress response as part of the plant stress network. In Biochemical and Cellular Mechanisms of Stress Tolerance in Plants (Cherry, J.H., ed.), Springer-Verlag, Berlin, pp. 3-45.

Pérez-Pérez, J.M., Ponce, M.R. and Micol, J.L. (2004) The ULTRACURVATA2 gene of Arabidopsis encodes an FK506-binding protein involved in auxin and brassinosteroid signaling. Plant Physiol. 134, 101-117.

Perona, R. and Serrano, R. (1988) Increased $\mathrm{pH}$ and tumorigenicity of fibroblasts expressing a yeast proton pump. Nature 334, 438-440.

Piper, P.W., Mahé, Y., Thompson, S., Pandjaitan, R., Holyoak, C., Egner, R., Mülbauer, M., Coote, P.J. and Küchler, K. (1998) The Pdr12 ABC transporter is required for the development of weak organic acid resistance in yeast. EMBO J. 17, 4257-4265.

Portillo, F. and Serrano, R. (1989) Growth control strength and active site of yeast plasma membrane ATPase studied by site-directed mutagenesis. Eur J Biochem 186, 501-507.

Prieto-Dapena, P., Castaño, R., Almoguera, C. and Jordano, J. (2006) Improved resistance to controlled deterioration in transgenic seeds. Plant Physiol. 142, 1102-1112.

Prodromou, C., Siligardi, G., O’Brien, R., Woolfson, D.N., Regan, L., Panaretou, B., Ladbury, J.E., Piper, P.W. and Pearl, L.H. (1999) Regulation of Hsp90 ATPase activity by tetratricopeptide repeat (TPR)-domain co-chaperones. EMBO J. 18, 754-762.

Raven, J.A. and Smith, F.A. (1976) The evolution of chemiosmotic energy coupling. J. Theor. Biol. 57, 301-312.

Riggs, D.L., Cox, M.B., Tardif, H.L., Hessling, M., Buchner, J.and Smith, D.F. (2007) Noncatalytic role of the FKBP52 peptidyl-prolyl isomerase domain in the regulation of steroid hormone signaling. Mol. Cell. Biol. 27, 8658-8669.

Sanchez, Y., Taulien, J., Borkovich, K.A. and Lindquist, S. (1992) Hsp104 is required for tolerance to many forms of stress. EMBO J. 11, 2357-2364.

Schüller, C., Brewster, J.L., Alexander, M.R., Gustin, M.C. and Ruis, H. (1994) The HOG pathway controls osmotic regulation of transcription via the stress response element (STRE) of the Saccharomyces cerevisiae CTT1 gene. EMBO J. 13, 4382-4389.

Schüller, C., Mamnun, Y.M., Mollapour, M., Krapf, G., Schuster, M., Bauer, B.E., Piper, P.W. and Kuchler, K. (2004) Global phenotypic analysis and transcriptional profiling defines the weak acid stress response regulon in Saccharomyces cerevisiae. Mol. Biol. Cell 15, 706-720

Serrano, R. (1985) Plasma Membrane ATPase of Plants and Fungi, Boca Raton, FL: CRC Press, Chapter 3, pp 48-52.

Serrano, R. (1988) $\mathrm{H}^{+}$-ATPase from plasma membranes of Saccharomyces cerevisiae and Avena sativa roots: purification and reconstitution. Meth Enzymol 157, 533-544.

Song, F., Zhang, X., Ren, X.B., Zhu, P., Xu, J., Wang, L., Li, Y.F., Zhong, N., Ru, Q., Zhang, D.W., Jiang, J.L., Xia, B. and Chen, Z.N. (2011) Cyclophilin A 
(CyPA) induces chemotaxis independent of its peptidylprolyl cis-trans isomerase activity: direct binding between CyPA and the ectodomain CD147. $J$. Biol. Chem. 286, 8197-8203.

Sorger, P.K. (1991) Heat shock factor and the heat shock response. Cell 65, 363-366

Sugio, A., Dreos, R., Aparicio, F. and Maule, A.J. (2009) The cytosolic protein response as a subcomponent of the wider heat shock response in Arabidopsis. Plant Cell 21, 642-654.

Takhashi, N., Hayano, T. and Suzuki, M. (1989) Peptidyl-prolyl cis-trans isomerase is the cyclosporin A-binding protein cyclophilin. Nature 337, 473-475.

Tena, G. and Renaudin, J.-P. (1998) Cytosolic acidification but not auxin at physiological concentration is an activator of MAP kinases in tobacco. Plant J. 16, 173-182.

Trotter, E.W., Kao, C.M.-F., Berenfeld, L., Botstein, D., Petsko, G.A. and Gray, J.V. (2002) Misfolded proteins are competent to mediate a subset of the responses to heat shock in Saccharomyces cerevisiae. J. Biol. Chem. 277, 44817-44825

Tusher, V.G., Tibshirani, R. and Chu, G. (2001) Significance analysis of microarrays applied to the ionizing radiation response. Proc. Natl. Acad. Sci. USA 98, 51165121.

Vallejo, C.G. and Serrano, R. (1989) Physiology of mutant with reduced expression of plasma membrane $\mathrm{H}^{+}$-ATPase. Yeast 5, 307-319.

Vandal, O.H., Nathan, C.F. and Ehrt, S. (2009) Acid resistance in Mycobacterium tuberculosis. J. Bacteriol. 191, 4714-4721.

Wang, Y., Liu, C., Yang, D., Yu, H. and Liou, Y.-C. (2010) Pin1At encoding a peptidyl-prolyl cis/trans isomerase regulates flowering time in Arabidopsis. Mol. Cell 37, 112-122

Weitzel, G., Pilatus, U. and Rensing, L. (1987) The cytoplasmic pH, ATP content and total protein synthesis rate during heat-shock protein inducing treatments in yeast. Exp. Cell Res. 170, 64-79.

Witte, C.-P., Noël, L.D., Gielbert, J., Parker, J.E. and Romeis, T. (2004) Rapid onestep protein purification from plant material using eight-amino acid StrepII epitope. Plant Mol. Biol. 55, 135-147.

Xu, J., Li, H.-D., Chen, L.-Q., Wang, Y., Liu, L.-L., He. L. and Wu, W.-H. (2006) A protein kinase, interacting with two calcineurin B-like proteins, regulates $\mathrm{K}^{+}$transporter AKT1 in Arabidopsis. Cell 125, 1347-1360.

Yenush, L., Mulet, J.M., Ariño, J. and Serrano, R. (2002) The Ppz protein phosphatases are key regulators of $\mathrm{K}^{+}$and $\mathrm{pH}$ homeostasis: implications for salt tolerance, cell wall integrity and cell cycle progression. EMBO J. 21, 920-929.

Yenush, L., Merchan, S., Holmes, J. and Serrano, R. (2005) pH-responsive, posttranslational regulation of the Trk1 potassium transporter by the type1related Ppz1 phosphatase. Mol. Cell. Biol. 25, 8683-8692.

Young, J.C., DeWitt, N.D. and Sussman, M.R. (1998) A transgene encoding a plasma membrane $\mathrm{H}^{+}$-ATPase that confers acid resistance in Arabidopsis thaliana seedlings. Genetics 149, 501-507. 
Table 1. Heat-shock response genes induced 2-fold or more by intracellular acid stress (Acid; this work) and by stress caused by misfolded cytosolic proteins (MCP) in Arabidopsis (Sugio et al., 2009). A dash indicates the gene is not induced. Genes in bold are induced by both stresses.

\begin{tabular}{|c|c|c|}
\hline Protein subfamily & Acid & MCP \\
\hline HSP100 & HSP101 & HSP101 \\
\hline HSP90 & HSP90.1 & HSP90.1 \\
\hline HSP70/K & $\begin{array}{l}- \\
- \\
- \\
\text { FES1A }\end{array}$ & $\begin{array}{l}\text { HSP70 } \\
\text { HSP70-2 } \\
\text { HSP70T-2 } \\
-\end{array}$ \\
\hline HSP40/J & $\begin{array}{l}- \\
- \\
-\end{array}$ & $\begin{array}{l}\text { At1g71000 } \\
\text { At2g20560 } \\
\text { At4g28480 }\end{array}$ \\
\hline small HSPs & $\begin{array}{l}\text { HSP23.5-M } \\
- \\
- \\
- \\
\text { HSP17.6C } \\
- \\
- \\
\text { HSP15.7-CI }\end{array}$ & $\begin{array}{l}\text { HSP23.5-M } \\
H S P 23.6-M \\
H S P 17.6 A \\
H S P 17.6 B \\
\text { HSP17.6C } \\
H S P 17.4 A \\
H S P 17.4 B \\
\text { HSP15.7-CI }\end{array}$ \\
\hline Prolyl isomerases & $\begin{array}{l}\text { ROF2 } \\
-\end{array}$ & $\begin{array}{l}\text { ROF2 } \\
\text { At1g01940 }\end{array}$ \\
\hline HSF & $\begin{array}{l}\text { HSFA2 } \\
\text { HSFA5 } \\
- \\
- \\
\text { HSFB1 }\end{array}$ & $\begin{array}{l}\text { HSFA2 } \\
- \\
\text { HSFB2A } \\
\text { HSFB2B } \\
\text { HSFB1 }\end{array}$ \\
\hline
\end{tabular}


Table 2. Germination of seeds of different genotypes after treatment in water during 23 $\mathrm{h}$ at $42{ }^{\circ} \mathrm{C}$. Non-treated seeds of all genotypes had 99-100 \% germination (seedlings with green cotyledons) after 4 days in MS medium. Data as mean \pm standard error (4 determinations). OERFO2 corresponds to line 17 over-expressing ROF2.

$\begin{array}{lr}\text { Genotypes } & \text { \% germination } \\ - \text { Wild type } & 33 \pm 5 \\ \text { rof1 } & 27 \pm 3 \\ \text { rof2 } & 38 \pm 2 \\ \text { rof1 rof2 } & 7 \pm 1 \\ \text { OEROF2 } & 32 \pm 4\end{array}$




\section{LEGENDS TO THE FIGURES}

Figure 1. Arabidopsis ROF1 and ROF2 prolyl isomerases modulate germination in media with weak organic acids.

(a) Representative seedlings of Arabidopsis wild type, rof1 mutant, rof2 mutant, double mutant rof1rof2, and line 17 over-expressing ROF2 (OE ROF2) 4 days after plating in normal pH 5.5 MS medium and in this medium supplemented with $3.5 \mathrm{mM}$ acetic acid or $3.5 \mathrm{mM}$ propionic acid as indicated. (b) Statistical data from 4 experiments like the one in part A. The mean per cent of seedlings with green, expanded cotyledons and the standard error are given. The size of the seedlings is also a measure of acid tolerance. (c) Weight of plants after germination in medium without acetic acid for 7 days and then growing in liquid medium for 12 days without (normal medium) or with $2 \mathrm{mM}$ acetic acid as indicated. The percent inhibition by the acid is calculated.

Figure 2. Developmental phenotypes of ROF mutants.

(a) Branching phenotype. Bud number refers to the number of secondary inflorescence shoots from axils of rosette leaves and were counted after 45 days of growth under longday illumination. Data are the mean of 30 plants and bars correspond to the standard error. Two ROF2 over-expressing lines (numbers 7 and 17) were employed. The yuc6$1 D$ mutants is presented as an example of high-auxin mutant with strong apical dominance (Kim et al., 2007). (b) Bolting phenotype. Bolting time (days after germination) and number of rosette leaves at time of bolting for the different genotypes grown under long-day illumination.

Figure 3. Over-expression of ROF2 increases proton extrusion from Arabidopsis roots. (a) Arabidopsis plants over-expressing ROF2 (line 17; OE ROF2) and control plants were incubated in solid MS medium at pH 5.5 without MES buffer and with $0.003 \%$ bromocresol purple. The yellow color of the $\mathrm{pH}$ indicator around OE ROF2 roots but not around control roots indicates increased proton extrusion in transgenic plants. (b) Quantification of proton efflux from roots. Each point is the average of three repetitions and the standard errors (not shown for clarity) were 0.005-0.010 $\mu$ moles $\mathrm{H}^{+}$.

Figure 4. Electrical membrane potential and cytosolic pH of ROF2 mutants. (a) Overexpression of ROF2 (line 10) depolarizes the plasma membrane and stabilizes cytosolic $\mathrm{pH}$ in the presence of acetic acid. Records of plasma membrane electrical potential $\left(\mathrm{E}_{\mathrm{m}}\right)$ and cytosolic $\mathrm{pH}(\mathrm{pH})$ of a root epidermal cell in a typical experiment. The addition (1 $\mathrm{mM} \mathrm{Ac}$ ) and removal (Wash) of acetic acid is indicated. (b): mean values ( \pm standard error, number of experiments between brackets) of membrane potential and cytosolic $\mathrm{pH}$ of control, (wild type Arabidopsis), OE ROF2 (line 10 over-expressing ROF2), rof2 (single mutant) and rof1 rof2 (double null mutant in ROF1 and ROF2).

Figure 5. Gain and loss of function of ROF2 modulate tolerance to toxic cations. (a) Representative seedlings of Arabidopsis wild type, double mutant rof1rof2, and line 17 over-expressing ROF2 (OE ROF2) after plating in normal MS medium and in medium supplemented with $25 \mathrm{mM} \mathrm{LiCl}$ (5 days), $2.8 \mathrm{mM}$ norspermidine (4 days) or $20 \mu \mathrm{g} / \mathrm{ml}$ hygromycin B (14 days) as indicated. Other conditions as in figure 1. (b) Statistical data from 4 experiments like the one in part (a). The mean per cent of seedlings with green, expanded cotyledons and the standard error are given. The size of the seedlings is also a 
measure of acid tolerance. Similar results were obtained with two additional transgenic lines (numbers 7 and 16, see supplementary figure S2).

Figure 6. Gain and loss of function of ROF2 modulate germination in low $\mathrm{K}^{+}$medium. (a) Representative seedlings of Arabidopsis wild type, double mutant rof1rof2, and line 17 over-expressing ROF2 (OEROF2) after plating in normal MS medium (control) and in medium with only $10 \mu \mathrm{M} \mathrm{K}^{+}$. Other conditions as in figure 1. (b) Statistical data from 4 experiments like the one in part (a).

Figure 7. Gain and loss of function of ROF2 modulate rubidium $\left(\mathrm{Rb}^{+}\right)$uptake. $\mathrm{Rb}^{+}$is utilized as an analog of $\mathrm{K}^{+}$. The uptake of $\mathrm{Rb}^{+}$at 15 and 30 min by Arabidopsis plants wild type, double mutant rof1rof2, and line 17 over-expressing ROF2 (OE ROF2) is shown. The experiment was repeated twice with similar results. 